\title{
Notes on Sparganium coreanum (Typhaceae) rediscovered on the Korean Peninsula
}

\author{
Young-Ho HA ${ }^{1,3 \dagger}$, Hee-Young GIL ${ }^{1 \dagger}$, Jungsim LEE ${ }^{1}$, Kang-Hyup LEE ${ }^{1}$, Dong-Hyuk LEE ${ }^{2}$, \\ Dong Chan SON ${ }^{1}$ and Kae Sun CHANG ${ }^{1 *}$ \\ ${ }^{1}$ Department of Forest Biodiversity and Herbarium, Korea National Arboretum, Pocheon 11186, Korea \\ ${ }^{2}$ Plant Survey and Conservation Team, Baekdudaegan National Arboretum, Bonghwa 36209, Korea \\ ${ }^{3}$ Department of Life Science, Gachon University, Seongnam 13120, Korea \\ (Received 4 July 2019; Revised 26 August 2019; Accepted 9 September 2019)
}

\begin{abstract}
Sparganium coreanum, a barely recognized species in Korea, was rediscovered during a field survey by the authors, who conducted a re-examination of specimens deposited in the Herbarium of the Korea National Arboretum (KH). This species was described initially by H. Léveillé from a specimen collected by F. Taquet from Jeju-do (Taquet 2150). Subsequently, however, it was overlooked and unrecognized among South Korean flora. Several populations of $S$. coreanum were found in the southern part of the Korean Peninsula and on Jeju-do, although it has long been recognized as $S$. erectum owing to certain vegetative morphological characteristics shared between the two species, such as robust stems, a similar plant height, and globose rhizomes. However, it is distinct from S. erectum by the number of female heads on the lowest inflorescence branch and the size and shape of the fruit. In this study, we provide a detailed description, illustrations, and photographs with a revised taxonomic key for identification of Sparganium species in Korea.
\end{abstract}

Keywords: Korean bur-reed, rediscovered species, Sparganium, Typhaceae

Sparganium L., a genus of monoecious perennial plant that belongs to the family of Typhaceae, consists of 14-19 species and mainly distributed in temperate and arctic regions of the Northern hemisphere (Cook and Nicholls, 1986, 1987; Sun and Simpson, 2010). It floats or sinks in ponds or swamps and plays an important ecological role by reducing riverbank erosion and providing food, shelter, and nest sites for wildlife (Cook and Nicholls, 1986). Furthermore, it is used for medicinal purposes such as improving blood circulation, reducing menstrual irregularity, and for its anticancer effects (Duke and Ayensu, 1985; Shirota et al., 1996; Lu et al., 1999; Tulin et al., 1999; Cho et al., 2006). Cook and Nicholls $(1986,1987)$ subdivided the genus into two subgenera (Xanthosparganium and Sparganium) based on the presence of a thickened dark brown to black pad at perianth segments and shape of perianth apex. However, Sulman et al. (2013) rearranged species in two subgenera suggested by Cook and Nicholls (1986) based on phylogenetic relationships and morphological characteristics of ovary and fruit.

In Korea, there are five species belonging to the genus Sparganium, which includes $S$. erectum L., S. japonicum Rothert, S. hyperboreum Laest. ex Beurl., S. fallax Graebn., and S. subglobosum Morong (Lee, 1980, 1996, 2006; Kim et al., 2010; Lim et al., 2017). S. coreanum H. Lév. was first described as a new species from specimen collected in Jeju-do (Taquet, 2150). Subsequently, S. coreanum has been recognized as an infra-specific taxon of $S$. stoloniferum $[S$. stoloniferum var. coreanum (H. Lév.) H. Hara] or S. eurycarpum [S. eurycarpum subsp. coreanum (H. Lév.) C. D. K. Cook \& M. S. Nicholls] (Cook and Nicholls 1986, 1987) or as a synonym of S. erectum var. macrocarpum (Makino) H.Hara and known to be distributed in Korea and Japan (Cook and Nicholls 1986, 1987). However, most Korean literature has not recognized $S$. coreanum (=S. stoloniferum var. coreanum) at all (Lee, 1996,

\footnotetext{
*Author for correspondence: natu17@korea.kr

These authors contributed equally to this work 
2003, 2006; Kim et al., 2010; Lim et al., 2017) with two exceptions of Im (1976) and Chang et al. (2014). Im (1976) mentioned the Korean vernacular name of this species, $S$. stoloniferum var. coreanum, for the first time as "Jo-seon-heuksam-neung (조선흑삼릉)" and classified three conspecific species of $S$. stoloniferum with fruit size and the number of female heads on an inflorescence branch. According to the classification of Im (1976), S. stoloniferum var. stoloniferum has smaller fruit than $S$. stoloniferum var. coreanum (i.e., 5-6 $\times 4 \mathrm{~mm}$ vs. $7-8 \times 5-7 \mathrm{~mm})$ and $S$. stoloniferum var. macrocarpum (Makino) H. Hara has small number of female heads (i.e., 1-3). However, Chang et al. (2014) treated $S$. coreanum as a synonym of $S$. erectum subsp. stoloniferum. In case of Japanese flora, although this species has been recognized as $S$. eurycarpum subsp. coreanum or $S$. erectum var. macrocarpum, its taxonomic status is still controversial (e.g., Yasuro, 2014; Ohashi et al., 2015). Therefore, a taxonomic study of $S$. coreanum and its relative species is required.

The aims of this study were to clarify the taxonomic entity of $S$. coreanum based on several literatures, herbarium specimens, and our field surveys and provide detailed morphological characteristics, illustrations, photographs of its habitats, and information of distribution in Korea. Furthermore, we suggested a taxonomic key for identification of Sparganium species in Korea.

\section{Taxonomic Treatment}

Sparganium coreanum H. Lév., Repert. Spec. Nov. Regni Veg. 10: 441, 1912.-TYPE: South Korea. "Quelpaert, in stagno Terok" (currently Jeju-do), 14 Sep 1908, Taquet 2150 (holotype E [seen as photo!]; isotypes G [not seen], K [seen as photo!], LE [seen as photo!], TI [not seen]). (Figs. 1, 2)

"Sparganium macrocarpum", Makino, Index Pl. Jap. [J. Matsumura] 2: 23, 1905, nom. nud.

S. macrocarpum Makino, J. Jap. Bot. 3: 22, 1926.

S. stoloniferum var. coreanum (H. Lév.) H. Hara, J. Jap. Bot. 12: 341, 1936.

S. stoloniferum var. macrocarpum (Makino) H. Hara, J. Jap. Bot. 12: 340, 1936.

S. erectum var. macrocarpum (Makino) H. Hara, J. Jap. Bot. 51: 229, 1976.

S. eurycarpum subsp. coreanum (H. Lév.) C. D. K. Cook \& M. S. Nicholls, Bot. Helv. 97: 28, 1987.

Perennial herb, monoecious, $1.0-1.2 \mathrm{~m}$ tall, glabrous, aquatic. Rhizomes creeping, globose. Stems robust. Leaves alternate, emergent, sheathed at base, linear, 50-130 cm long,
5-23 mm wide, midrib distinct and keeled abaxially, basally triangular. Inflorescence stems erect, 10-60 cm long; paniculate with $3-5$ branches; lateral branches ca. $10 \mathrm{~cm}$ long; the uppermost branch with 10-27 male heads, other branches with female and male heads or only 1-2 female heads; the lowermost branch with solitary female head; female heads ca. 7-10 mm in diam.; male heads $5-7 \mathrm{~mm}$ in diam.; bracts leaf-like, basal bract $18-40 \mathrm{~cm}$ long. Male flowers perianth segments 3 or 4 , spathulate, ca. $2-2.5 \mathrm{~mm}$ long, stamens 3 or more, filaments ca. $1.5-4 \mathrm{~mm}$ long, anthers basifixed, longitudinally dehiscent. Female flowers bracteolate; perianth segments spathulate, ca. 2-4 mm long; ovary sessile, ca. 2$4 \mathrm{~mm}$ long, 1 or 2 locules; 1 or 2 stigma, ca. 3-6 mm long. Fruit nutlike, rhombic, shallowly rounded or widely pyramidal apex, ca. $8-10 \mathrm{~mm}$ long, 5-8 $\mathrm{mm}$ wide, indehiscent; endocarps longitudinal ribs, 6-8 mm long, 3-5 mm wide.

Phenology: Flowering time May to August, fruiting time July to September.

Distribution: Korea (Jeju-do [Jeju-si, Seogwipo-si], Gyeongsangbuk-do [Gyeongsan-si, Yeongcheon-si], Jeollanamdo [Naju-si]), Japan (Honshu).

Vernacular name (English and Korean): Korean bur-reed, 조선흑삼릉(Jo-seon-heuk-sam-neung).

Taxonomic notes: Even though the type locality of $S$. coreanum was Jeju-do (Jeju Island), South Korea, this species has been overlooked and unrecognized in South Korean flora. Several populations of $S$. coreanum found in this study were identified as $S$. erectum. Since $S$. coreanum was described by Léveillé (1912), taxonomic status of this species was controversial. It has been considered as an infra-specific taxon, either S. stoloniferum var. coreanum or S. eurycarpum subsp. coreanum (Hara, 1936; Cook and Nicholls, 1987) or as a synonym of $S$. erectum var. macrocarpum because of vegetative morphological characteristics such as panicle inflorescences, robust stems, long stigmas ( $\geq 3 \mathrm{~mm}$ ), and plant heights are similar among $S$. coreanum, $S$. erectum $(=S$. stoloniferum), and $S$. eurycarpum. Previous phylogenetic study suggested that $S$. erectum and $S$. eurycarpum complexes are early diverged basal groups in Sparganium and mainly distributed in Eurasia and North America (Sulman et al., 2013). Morphological characteristics are very similar between two groups but the most important characteristic to distinguish two groups is the ratio of flowers with two carpels and single carpel in female head (Cook and Nicholls, 1986). For example, more than half of the female flowers of the $S$. eurycarpum group have bifid styles and two carpels, whereas less than half of the female flowers of the $S$. erectum group have such ones. 


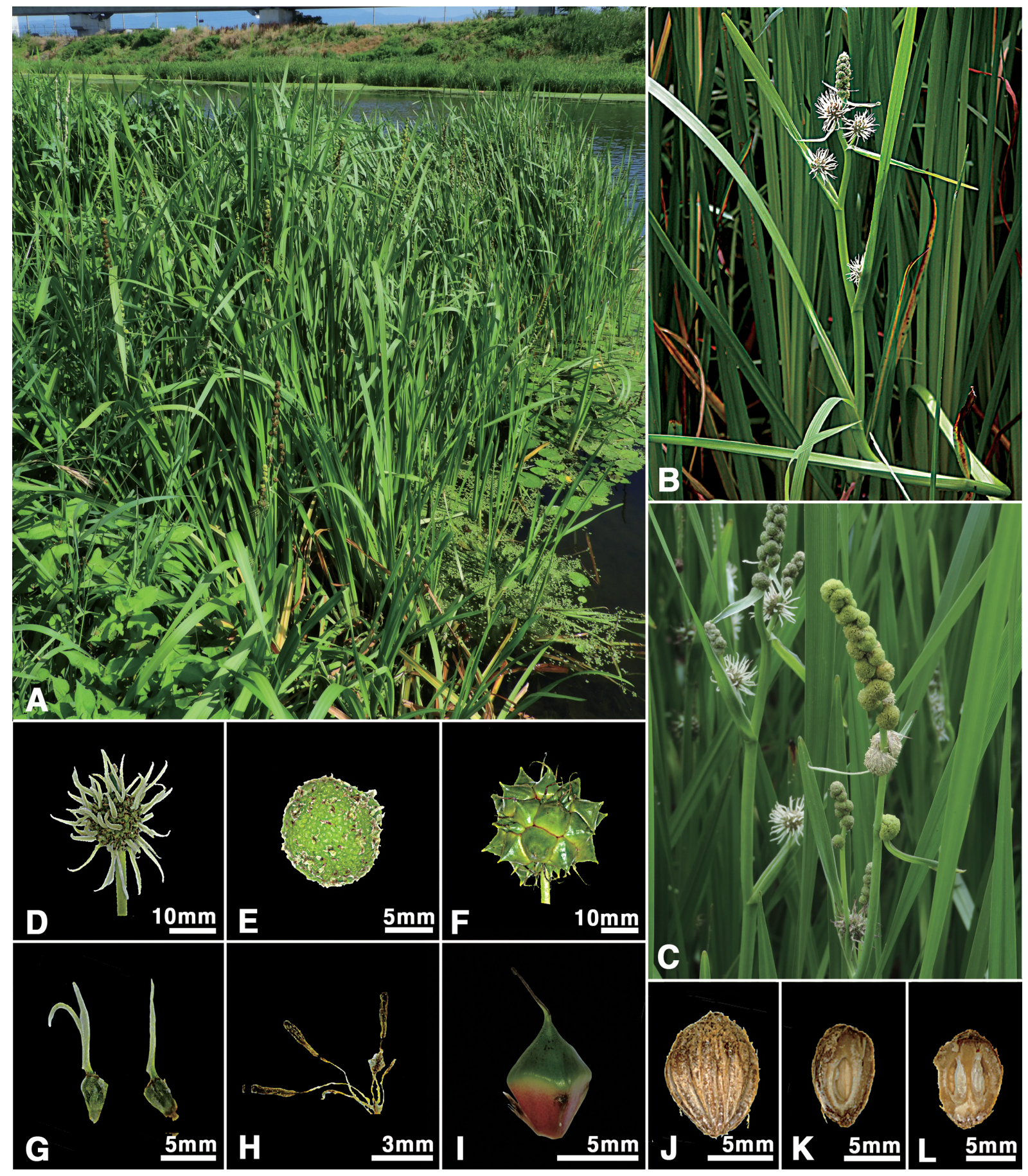

Fig. 1. Photographs of Sparganium coreanum (Typhaceae). A. Habit. B, C. Inflorescence. D. Matured female head. E. Immature male head. F. Fruits in a head. G. Pistillate flower. H. Staminate flower. I. Fruit. J. Endocarp. K, L. Cross section of endocarps (K, one carpel; L, two carpels).

Although Cook and Nicholls (1987) treated $S$. coreanum as a S. eurycarpum subsp. coreanum, the individuals of $S$. coreanum from Japan and Korea observed in this study showed $S$. erectum type female head. In case of type specimen collected by Taquet, it was not possible to confirm whether the female heads are $S$. erectum or $S$. eurycarpum type since the stigmas of the fruit had already fallen off and it was not possible to check the number of carpels by photographs. However, individuals 


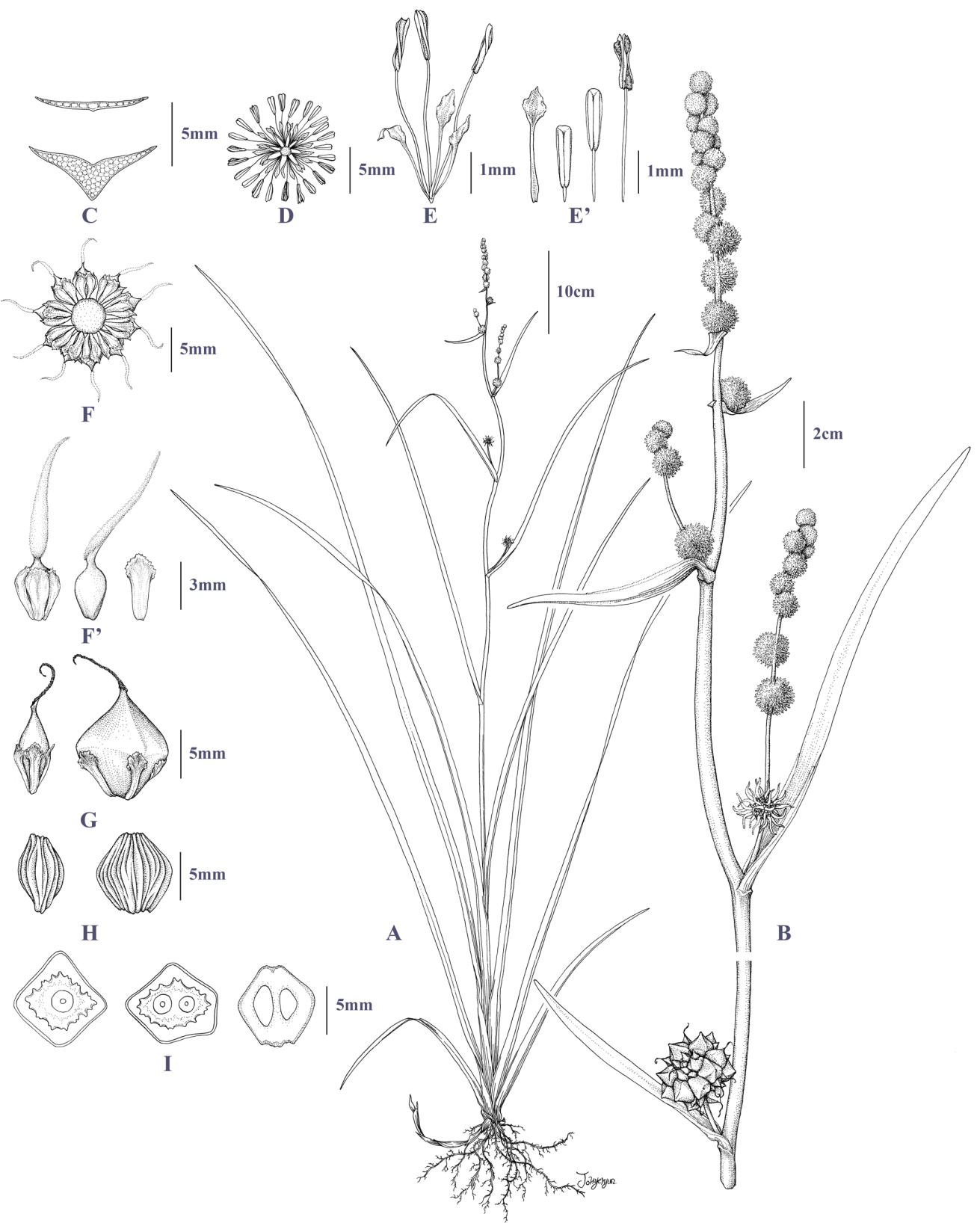

Fig. 2. Illustrations of Sparganium coreanum (Typhaceae). A. Habit. B. Detailed part of inflorescence. C. Leaves lower bracts. D. Male head. E. Staminate flower. E'. Detailed part of staminate flower (Spathulate perianth, Sequential stamen maturation). F. Longitudinal section of female head. F'. Detailed part of pistillate flower (Pistillate flower, Carpel, and Spathulate perianth). G. Fruits (Left: immature, Right: mature). H. Endocarps (left, one-carpeled; right, two-carpeled). I. Transverse section of fruits (left and middle, transverse section, seed[s] included in irregular shape of endocarp) and longitudinal section of endocarp (right, seeds in endocarp).

collected from Jeju-do, where the type specimen was acquired, showed S. erectum type female head. Even though we could not check the S. coreanum specimens Cook and Nicholls (1986) observed because no information was provided, it is likely that they considered it as a subspecies of $S$. eurycarpum after observing some exceptional individuals.

When compared to $S$. erectum, however, S. coreanum had only one or two female head on the lowermost inflorescence branch and rhombic fruit, while $S$. erectum had both male and female head on the lowermost inflorescence branch and variable in forms of fruit (Cook and Nicholls, 1987). Phylogenetic tree of nrDNA internal transcribed spacer data showed that $S$. coreanum is monophyletic and has sister relationship with $S$. eurycarpum rather than to $S$. erectum 
(unpublished data). Considering the morphological distinction and phylogenetic relationships, we suggest $S$. coreanum to be an independent taxon rather than a infraspecies of $S$. erectum or S. eurycarpum. S. erectum var. macrocarpum has no morphological difference but larger fruit than $S$. coreanum and it has continuous variation not only in a single community but also in a single individual. Therefore, $S$. macrocarpum was treated as a synonym of $S$. coreanum in this study.

Distribution and ecological status: To date, there are five species in the genus of Sparganium that are known in Korea, and most of the species except for $S$. erectum and S. japonicum occur in limited areas with small populations. S. coreanum is also distributed in limited areas in Korea and Japan, the latter in which it is protected and managed as a second-class endangered species (Yasuro, 2014). This study confirms the native habitats of $S$. coreanum in Korea, which include Naju, Jeollanam-do, Gyeongsan and Yeongcheon in Gyeongsangbukdo, and Sanggye-ri and Haga-ri in Andeok-myeon, Jeju-do where it grows on the edge of rivers and wetlands. In the habitat of Andeok-myeon, Jeju-do, temporary wetlands have been created due to seasonal and climatic effects. It has a relatively higher plant diversity and large number of individuals, although being private land, regional development involving the construction of housing is damaging the habitat. Even though another population of S. coreanum, Yeonhwamot Pond located in Haga-ri, was discovered from Jeju-do during our reexamination of herbarium specimens deposited in the Herbarium of Korea National Arboretum (KH), it no longer exists due to construction for visitor facility. Given the habitat specificity of aquatic plant, $S$. coreanum, most of populations of this species are highly threatened from anthropogenic disturbances such as constructions for housing and visitor facilities. Further extensive field investigations are needed to determine the population sizes and more precise distributions in Korea.

Specimens examined: KOREA. Jeju-do: Jeju-si, Aewoleup, Haga-ri, Yeonhwamot, 24 Jun 2013, Halla0466 (KH); Seogwipo-si, Andeok-myeon, Sagyeri, 26 Jul 2018, LEE.JS20180001， LEE.JS20180002， LEE.JS20180003, LEE.JS20180004 (KH); 7 Sep 2018, GIL2784, GIL2785 (KH); 6 Dec 2018, HYH20180101, HYH20180102 (KH). Gyeongsangbuk-do: Gyeongsan-si, Amnyang-myeon, Baeganri, 10 Jul 2018, Choi2018001, Choi2018002 (KH); 8 Jan 2013, DJUIDC2013-124 (KH); 28 Jun 2011, Nakdong-2114 (KH); Yeongcheon-si, Beomeo-dong, Beomeoje, 22 Jul 2004, 2004AJOU (KH). Jeollanam-do: Naju-si, Gongsan-myeon, Dongchon-ri, Useupje, 25 Sep 2013, 2013JNV061 (KH).

\section{Key to Sparganium species in Korea}

1. Inflorescences paniculate; ovaries unilocular or bilocular; stigmas longer than $3 \mathrm{~mm}$ and bifid or not.

2. Lowest inflorescence branch born axillary with male and female heads; fruits fusiform to spherical, $6-9 \mathrm{~mm}$ long and $2.5-5 \mathrm{~mm}$ wide ……………... S. erectum

2. Lowest inflorescence branch born axillary with 1-2 female heads only; fruits rhombic and domed or widely pyramidal above, $8-10 \mathrm{~mm}$ long and 5-8 $\mathrm{mm}$ wide S. coreanum

1. Inflorescences racemose or spicate; ovaries unilocular; stigmas less than $3 \mathrm{~mm}$ and not bifid.

3. Plants robust, 1-2 $\mathrm{m}$ high; inflorescences not branching; fruits fusiform.

4. Inflorescence bracts erect; female heads usually supra-axillary …....................................... S. fallax

4. Inflorescence bracts spreading or ascendingspreading; female heads usually axillary with distinct peduncle ………….............. S. japonicum

3. Plants slender, shorter than ca. $1 \mathrm{~m}$; inflorescences branching; fruits obovoid.

5. Stems erect; leaves not flattened, with distinct midrib, a keel or trigonous on abaxial side. Main axis consisting of 5-7 male heads. Perianth segments translucent without dark-brown pad near apex …......................................... S. subglobosum

5. Stems floating; leaves flat, without distinct midrib and without a keel; male heads 1 or 2, smaller. Perianth segments not translucent with dark-brown pad near apex ………………....... S. hyperboreum

ORCID: Young-Ho HA https://orcid.org/0000-0002-23743611; Hee-Young GIL https://orcid.org/0000-0003-3714-0827; Jungsim LEE https://orcid.org/0000-0003-2815-6464; KangHyup LEE https://orcid.org/0000-0002-7189-3235; DongHyuk LEE https://orcid.org/0000-0003-0008-5510; Dong Chan SON https://orcid.org/0000-0002-6773-0580; Kae Sun CHANG https://orcid.org/0000-0003-4454-6059

\section{Acknowledgments}

This research was carried out as part of a research project of the Korea National Arboretum, "A Taxonomic Review of Juncaceae and Eriocaulaceae in the Korean Peninsula (KNA11-21, 17-1)." We would like to thank Soo Hyun Park, Kyoung Su Choi, and Chang-Seok Jang for their fieldwork and literature review. Also, we are grateful to Hyeryun Jo for her hard work with the illustrations. 


\section{Conflict of Interest}

The authors declare that there are no conflicts of interest.

\section{Literature Cited}

Chang, C.-S., H. Kim and K. S. Chang. 2014. Provisional Checklist of Vascular Plants for the Korea Peninsula Flora (KPF). Designpost, Paju, 563 pp.

Cho, S.-I., S.-J. Cho, B.-Y. Kim and Dhayal, M. 2006. Anticancer activities of Sparganium stoloniferum on the proliferation of MCF-7 cells. Journal of Biomedical Nanotechnology 2: 125128.

Cook, C. D. K. and M. S. Nicholls. 1986. A monographic study of the genus Sparganium (Sparganiaceae). Part 1. Subgenus Xanthosparganium Holmberg. Botanica Helvetica 96: 213-267.

Cook, C. D. K. and M. S. Nicholls. 1987. A monographic study of the genus Sparganium (Sparganiaceae). Part 2. Subgenus Sparganium. Botanica Helvetica 97: 1-44.

Duke, J. A. and E. S. Ayensu. 1985. Medicinal Plants of China, Vol. 2. Reference Publishing, Algonac, MI, 705 pp.

Hara, H. 1936. Observations ad plantas Asiae Orientalis. Journal of Japanese Botany 12: 339-341.

Im, R. J. 1976. Flora Coreana. Vol. 7. Scientiarum R.P.D.C, Phyongyang. Pp. 31-32. (in Korean)

Kim, C.-S., S.-Y. Kim and M.-O. Moon. 2010. A new record for the Korean flora: Sparganium fallax Graebn. (Sparganiaceae). Korean Journal of Plant Taxonomy 40: 169-173. (in Korean)

Lee, T. B. 1980. Illustrated Flora of Korea. Hyangmunsa, Seoul. Pp. 296-297. (in Korean)

Lee, T. B. 2003. Coloured Flora of Korea. Vol. 2. Hyangmunsa, Seoul. Pp. 408-409. (in Korean)

Lee, W. T. 1996. Linneamenta Florae Koreae. Academy Publishing Co., Seoul. Pp. 1438-1441. (in Korean)
Lee, Y. N. 2006. New Flora of Korea. Vol. 2. Kyohaksa, Seoul, 885 pp. (in Korean)

Léveillé, H. 1912. Decades plantarum novarum. Repertorium Specierum Novarum Regni Vegetabilis 10: 369-378. (in French)

Lim, C.-K., J. Kim, Y. C. Kim, C. E. Lim and H. Won. 2017. First record of Sparganium subglobosum Morong (Typhaceae) from Korea. Korean Journal of Plant Taxonomy 47: 322-327.

Lu, T., D. Ye, C. Ma and X. Liu. 1999. Studies on antiplatelet aggregation and antithrombosis action of total flavonoids of common Burreed (Sparganium stoloniferum). Chinese Traditional and Herbal Drugs 30: 439-440.

Ohashi, H., Y. Kadoda, H. Kihara, H. Tomita and K. Yonekura. 2015. Revised New Edition Wild Flowers of Japan. Vol. 1. Cycadaceae-Cyperaceae. Heibonsha. Pp. 227-228. (in Japanese)

Shirota, O., S. Sekita, M. Satake, Y. Ni and H. Weiyi. 1996. Chemical constituents of Chinese folk medicine "Sân Léng", Sparganium stoloniferum. Journal of Natural Products 59: 242245.

Sulman, J. D., B. T. Drew, C. Drummond, E. Hayasaka and K. J. Sytsma. 2013. Systematics, biogeography, and character evolution of Sparganium (Typhaceae): diversification of a widespread, aquatic lineage. American Journal of Botany 100: 2023-2039.

Sun, K. and D. A. Simpson. 2010. Sparganium. In Flora of China. Vol. 23. Acoraceae through Cyperaceae. Wu, Z. Y., P. H. Raven and D. Y. Hong (eds.), Science Press, Beijing and Missouri Botanical Garden Press, St, Louis, MO. Pp. 158-161.

Tulin, L., Y. Dingjiang and M. Chunqin. 1999. Studies on antiplatelet aggregation and antithrombosis action of total flavonoids of common burreed (Sparganium stoloniferum). Chinese Traditional and Herbal Drugs 30: 439-440.

Yasuro, K. 2014. A Field Guide to Aquatic Plants of Japan. Bunichi sogo Suhppan, Tokyo, 326 pp. (in Japanese) 